\title{
Microbial dynamics in autotrophic and heterotrophic seawater mesocosms. I. Effect of phytoplankton on the microbial loop
}

\author{
Uta Passow ${ }^{1, *}$, Christina L. De La Rocha ${ }^{1}$, Carol Arnosti ${ }^{2}$, Hans-Peter Grossart ${ }^{3}$, \\ Alison E. Murray ${ }^{4}$, Anja Engel ${ }^{1}$ \\ ${ }^{1}$ Alfred-Wegener-Institut für Polar- und Meeresforschung, Am Handelshafen 12, 27570 Bremerhaven, Germany \\ ${ }^{2}$ Department of Marine Sciences, University of North Carolina, Chapel Hill, North Carolina 27599-3300, USA \\ ${ }^{3}$ Institute of Freshwater Ecology and Inland Fisheries, Dept. of Limnology of Stratified Lakes, Alte Fischerhütte 2, \\ 16775 Stechlin, Germany
}

${ }^{4}$ Division of Earth and Ecosystem Science, Desert Research Institute, 2215 Raggio Parkway, Reno, Nevada 89512, USA

\begin{abstract}
The effect of phytoplankton on the other compartments of a simple microbial loop consisting of dissolved matter, bacteria and nanoflagellates was investigated in three 10001 mesocosms. These mesocosms were inoculated with a natural bacterial community and (1) no other additions (No Addition tank), (2) Phaeocystis globosa (Phaeocystis tank), or (3) 2 diatom species (Diatom tank). During the $20 \mathrm{~d}$ experiment, autotrophic activity was negligible in the No Addition tank. In contrast a small P. globosa bloom developed in the Phaeocystis tank and a large diatom bloom dominated the Diatom tank. In this paper we describe the experiment, the changes in chlorophyll a and heterotrophic nanoflagellate concentrations, as well as the cycling of nitrogen, phosphorus, and silica. Then we provide a synthesis of the structure and functioning of the microbial loops in these 3 systems using cluster analysis, a statistical pattern recognition tool. The goal was to test the hypothesis that differences in the resident phytoplankton populations would be reflected in (1) the composition and concentration of dissolved organic matter, (2) the composition of the bacterial community, (3) the food web, and (4) the cycling of elements and organic matter. In all 3 mesocosms, nitrate and silicic acid remained abundant. Orthophosphate was preferred by diatoms, whereas Phaeocystis appeared to prefer dissolved organic phosphorus. The hypothesis that phytoplankton composition shapes the structure and functioning of the microbial loop was partially supported: $6 \mathrm{~d}$ after inoculation each mesocosm exhibited a distinct organic matter signature. After 10 to $12 \mathrm{~d}$, concentrations of heterotrophic nanoflagellates were high enough to exert significant grazing pressure in all 3 mesocosms. A parallel shift in bacterial community composition was visible in all mesocosms at this time, possibly reflecting grazing pressure. The food-web structure developed divergently in the 3 mesocosms during the second half of the experiment. Differences in biochemical cycling between mesocosms were predominantly driven by the large quantitative differences in autotrophs.
\end{abstract}

KEY WORDS: Mesocosm • Microbial loop · Structure and function - Food-web structure · Cluster analysis Resale or republication not permitted without written consent of the publisher

\section{INTRODUCTION}

About 20 yr ago, the central role of bacteria and flagellates in many marine pelagic systems was recognized. The term 'microbial loop' was introduced (see also Azam et al. 1983) to describe the coupling between eukaryotic phytoplankton, the particulate and dissolved organic carbon they produce, bacteria (heterotrophic, photoheterotrophic, photoautotrophic, or chemoautotrophic), archaea, viruses and their pro- 
tist grazers, as well as mixotrophic protists. The relationship of the different components of the microbial loop to one another is complex, with each compartment both influencing and being influenced by the others. Bacterial activity and community composition, for example, modify and are modified by the quality and quantity of dissolved organic matter (DOM), which, in turn, is a result of DOM release, which is a function of phytoplankton composition, growth and exudation (Pinhassi et al. 1999, Riemann et al. 2000, Castberg et al. 2001, Fandino et al. 2001, Schäfer et al. 2001), grazing (Šimek et al. 1997, 2001, Lebaron et al. 1999), and viral lysis (Fuhrman 1999).

These links between organic carbon, bacteria (used here to encompass Bacteria and Archaea), viruses, and protists mean that the species composition and physiological state of the autotrophic community in a given system may profoundly affect the bacterial and protist communities. Whereas we recognize the importance of phytoplankton composition (e.g. diatoms vs. coccolithophores or nitrogen fixers) for biochemical cycling, potential differences in the structure and functioning of the associated microbial loops are rarely considered. Potentially, shifts in phytoplankton composition could, for example, cause modifications in DOM composition, resulting in adjustments of the bacterial community structure and degradation rates, leading to variations in the biochemical cycling of elements and organic matter and in the export efficiency of organic matter. Highly controlled experiments that would be required to study the effect of phytoplankton on the microbial loop are impossible in the field due to many potentially confounding physical and biological factors: the patch under investigation might, for example, be diluted due to mixing or advection, or the arrival of swimmers may change the food web.

Mesocosms ( 200 to 15000 l) allow for the controlled manipulation of a water body large enough to adequately host the different compartments of the microbial food web. While mesocosms are generally too small to support a food web that includes large zooplankton, they sustain microbial food webs adequately for days to weeks and have been used successfully to investigate microbial dynamics after perturbations of the environment. Some such studies have focused on the development or decline of phytoplankton blooms (e.g. Alldredge et al. 1995, Engel et al. 2002) or on the interactions between different microbial loop organisms (Castberg et al. 2001, Larsen et al. 2001, Brussaard et al. 2005). Other studies have concentrated on changes in the composition of organic matter (Meon \& Kirchman 2001) or on the bacterial community. Enrichment of natural seawater with nutrients often permits a growth spurt of bacteria and a subsequent increase in protists, allowing investigations of the effects of a growth and a grazing phase on the bacterial community (Lebaron et al. 1999, 2001, Schäfer et al. 2001, Troussellier et al. 2005). Other investigations have examined possible direct effects of nutrient addition (organic or inorganic) on microbial communities (Pinhassi et al. 1999, Øvreås et al. 2003), or on the competition between bacterial and phytoplankton communities (Havskum et al. 2003). Studies focusing on the post-bloom phase of phytoplankton, when colonization of decaying diatoms is accompanied by shifts in bacterial community composition and increases in abundance and hydrolytic activity of bacteria, have also been conducted (Riemann et al. 2000). Most of these investigations have studied specific aspects or processes of the microbial loop rather than trying to understand and characterize the structure and functioning of the microbial loop in its entirety. Furthermore, the effect of phytoplankton composition on the different components of the microbial loop has not previously been addressed.

We therefore set up a series of mesocosms to investigate the influence of the phytoplankton community on organic matter composition, the activity and composition of the bacterial community, the food-web structure, and associated biochemical cycling. The phytoplankton chosen, Phaeocystis globosa and the diatoms Chaetoceros decipiens and Thalassiosira pseudonana, are all bloom formers, potentially able to build up a large autotrophic biomass, but they belong to different functional groups. Diatoms require silicic acid for growth and play a significant role in transporting carbon to the deep ocean. Diatoms generate transparent exopolymer particles (TEP) and form large aggregates which sink (Passow 2002). Phaeocystis flagellates, in contrast, are small and mobile, but may form large carbon-rich colonies. Phaeocystis spp. generate abundant TEP and are known for their generally high production of mucilage, which often accumulates as foam at the water surface. Sedimentation events are possible after Phaeocystis spp. blooms, but depend on the presence of other particles in the water (Wassman et al. 1995).

The main hypothesis of this experiment was that differences in the dominating phytoplankton population would be reflected in the composition and concentration of DOM, and in the microbial community and the cycling of elements. The 3 mesocosms initially differed in their autotrophic population only. The biology and biochemistry of the evolving microbial loop community was monitored over a $20 \mathrm{~d}$ period. In the present paper, which gives an overview of the experiment, we present data on the distributions of chlorophyll a ( $\mathrm{chl} a$ ) and heterotrophic nanoflagellates (HNAN) and on nitrogen, phosphorus, and silica cycling. Additionally, analyses of the similarities and differences in the 
development of the microbial loops in the 3 mesocosms based on all data collected (Grossart et al. 2007, this issue, Murray et al. 2007, this issue) are provided. Murray et al. (2007) relate temporal changes in the bacterial community composition to variations in organic matter composition and utilization by comparing the composition of the bacterial community structure to changes in enzymatic hydrolysis rates and organic matter composition. Grossart et al. (2007) present changes in the composition of organic matter and assembles biogeochemical budgets.

\section{MATERIALS AND METHODS}

Experimental set-up. Three rectangular, $1000 \mathrm{l}$ polypropylene tanks (1.65 $\mathrm{m}$ depth) were filled with prefiltered water collected from $2 \mathrm{~m}$ depth in the North Sea, near Helgoland, Germany. Mesocosms and filtration systems were cleaned thoroughly before use to avoid contamination with dissolved organic carbon (DOC). Mesocosms were scrubbed and wiped with alcohol, the $1.2 \mu \mathrm{m}$ cartridge was rinsed and autoclaved, and the ultrafiltration system was acid rinsed (phosphoric acid), followed by a rinse with sodium hydrochloride. Because high wind conditions at the time of collection promoted the inflow of water from the Elbe River, the collected water was high in nitrate $(\geq 56 \mu \mathrm{M})$ and relatively low in salinity $(30 \%)$. Fresh water influence was also visible in the bacterial composition (Murray et al. 2007). The water was stored in the dark for $48 \mathrm{~h}$ prior to the start of the experiment so that coarse particulates could settle. Half of the water was then filtered through a $1.2 \mu \mathrm{m}$ cartridge filter. To diminish the initial microbial population and the concentrations of colloidal organic carbon, the remaining half of the water was ultra-filtered to remove all material larger than $50 \mathrm{kDa}$ (Millipore, Pellicon). The filled tanks were mixed overnight by an airlift system before the experiment was started.

To the No Addition tank, nothing further was added. To the Phaeocystis tank, 1.51 of a culture of solitary $P$. globosa was added to produce a cell concentration of

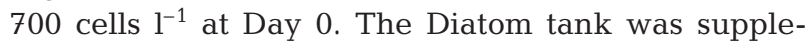
mented with $15 \mu \mathrm{mol} \mathrm{l^{-1 }}$ of silicic acid as sodium metasilicate and inoculated with $3 \mathrm{l}$ each of axenic cultures of Chaetoceros decipiens (CCMP173) and Thalassiosira pseudonana (CCMP 1013), producing an initial cell concentration of approximately 300 and 3000 cells $^{-1}$, respectively. Assuming a growth rate of 0.5 and $0.25 \mathrm{~d}^{-1}$ for the diatoms and Phaeocystis spp., respectively, these initial cell concentrations would have resulted in blooms after $8 \mathrm{~d}$ equivalent to particulate organic nitrogen (PON) concentrations of $10 \mu \mathrm{M}$. The first samples were taken $17 \mathrm{~h}$ after addition of the inoculi to ensure that the added phytoplankton was well mixed within the mesocosms.

Water temperature in the indoor mesocosms was always between 11.0 and $11.3^{\circ} \mathrm{C}$, and each mesocosm received $250 \mu \mathrm{E} \mathrm{m}^{-2} \mathrm{~s}^{-1}$ light at the water surface under a 16:8 h light:dark cycle, mirroring the contemporaneous light cycle at the sampling site. The mesocosms were continuously mixed using an airlift system. The airlift system slowly moved water from the bottom of the mesocosm to the top, through a tube into which air was injected into the lower half of the tube (Egge \& Aksnes 1992). Mixing by this airlift system did not promote aggregation of small particles as can be seen from the size distributions of TEP and Coomassiestained particles (CSP) (U. Passow unpubl. data). Conductivity/temperature/depth (CTD) profiles indicated no stratification in the tanks, and $\mathrm{pH}$ remained between 8.0 and 8.2 in all mesocosms at all times.

The experiment was conducted for $20 \mathrm{~d}$, and samples were taken every $2 \mathrm{~d}$ (except initially, when the interval was $3 \mathrm{~d}$ ) from about $20 \mathrm{~cm}$ below the surface. Data were graphed in real time, but are referred to in whole days for ease of reading, e.g. Day 0.7 is called Day 1. Samples were processed immediately after collection.

Analysis of chlorophyll and abundance of heterotrophic flagellates. Chl a samples were collected on pre-combusted GF/F filters (Whatman), extracted in $90 \%$ acetone, and measured using a fluorometer (Turner TD 10). HNAN were collected on black filters ( $0.8 \mu \mathrm{m}$ polycarbonate, Poretics, filtering 3 to $20 \mathrm{ml}$ filter $^{-1}$ ), fixed with glutaraldehyde, stained immediately with DAPI, and stored frozen for a few weeks until triplicate filters were counted via fluorescence microscopy (Kemp et al. 1993) at a magnification of $400 \times$ to $1000 \times$. Autofluorescence was used to distinguish heterotrophic from autotrophic flagellates.

Analysis of inorganic nutrients, dissolved organic phosphorus (DOP), particulate organic phosphorus (POP), particulate organic nitrogen (PON), and biogenic silica (BSi). Samples for nitrate, nitrite, and phosphorus were filtered (GF/F, Whatman) and kept frozen until determination on a nutrient autoanalyzer (Technicon ASM II). Concentrations of soluble reactive phosphorus and silicic acid were measured manually using a spectrophotometer. Autoanalyzer and manual determinations of orthophosphate $\left(\mathrm{PO}_{4}{ }^{3-}\right)$ agreed well, and averages of both were used. DOP was calculated from TP (total phosphorus) and $\mathrm{PO}_{4}{ }^{3-}$. TP was determined colorimetrically after persulfate oxidation (Koroleff 1983). Silicic acid concentrations were determined via molybdate blue spectrophotometry (Strickland \& Parsons 1968) using a reverse-order reagent blank.

Samples for PON were collected on pre-combusted GF/F filters and then measured using an elemental 
analyzer (ANCA SL 20-20), together with POC. POP was also collected on pre-combusted GF/F filters, digested, and measured colorimetrically (Koroleff 1983). BSi was collected on $0.6 \mu \mathrm{m}$ polycarbonate filters (Millipore), dissolved in 2.5 M hydrofluoric acid, and measured colorimetrically (Strickland \& Parsons 1968) using a spectrophotometer.

Comparison of mesocosms. The degree of similarity between the 3 mesocosms was assessed to test the hypothesis that phytoplankton community composition will lead to the establishment of microbial loop communities differing in their standing stocks, composition, and functioning. This analysis was based on all data collected during the experiment. An overview is given in Table 1, and more details are presented in the 2 companion papers as referenced in Table 1. Averages ignore temporal development, so differences were compared using clustering approaches.

Clustering is an exploratory analysis that results in data reduction, facilitating detection of underlying patterns in large data sets. We analyzed differences between samples based on temporal changes or distinct phytoplankton communities (mesocosms) using a 1-dimensional clustering approach. This unweighted pair-group method using the arithmetic average (UPGMA) clustering approach was based on Euclidean distance, in which missing data were replaced by the means for the respective variables (Statistica, v. 6.1). Euclidean distance is simply the geometric distance in a multidimensional space, defined by the independent variables. Small distances between samples identify similarities based on the parameters used in that particular analysis, allowing conclusions on the degree of similarity between mesocosms and the degree of temporal change within each mesocosm to be made. Different clustering analysis approaches were explored and compared. Whereas the exact days when transitions between phases occurred sometimes varied between analysis tools, which reflects the fact that transitions were continuous, the emerging patterns were similar using all approaches tested. As differences in scale can affect the results, the organism concentrations for the food-web dendrograms were normalized. The trees were constructed in Treeview v.1.60 (http//:rana.lbo.gov).

In order to investigate the overarching hypothesis, all data collected were grouped into 4 categories: (1) \% monomer composition, (2) gene phylotypes, (3) foodweb data, and (4) biochemical data (Table 1). Categories were chosen to represent one part of the hypothesis, e.g. the '\% monomer composition' category included the percent monomer composition of all neutral carbohydrates and amino acids and provided the basis for the hypothesis that phytoplankton composition directly or indirectly influenced the ambient (measurable) DOM composition. The 'phylotypes' category includes the relative abundance of DGGE SSU rRNA phylotypes and clustering results depict the effect of treatment (phytoplankton) on bacterial community composition. The 'food-web' category includes standing stocks and activities (production, respiration, hydrolysis rates) of the different organism types and of non-living particles. A more detailed analysis of foodweb functioning includes potential interactions between organisms or organisms and particles (grazing, viral lysis, attachment), which is being done elsewhere (U. Passow et al. unpubl. data) and could not be included in this analysis as results were too qualitative. The category termed 'biochemical' includes dissolved and particulate inorganic and organic elements, as well as complex organic molecules and describes the cycling of these substances. Each category included roughly a similar number of parameters. In similarity trees resulting from the clustering analysis, the distance between 2 samples expresses the degree of similarity between those samples based on the parameters of that category. The interpretation of the 4 dendrograms thus permits an overall evaluation of the effect of phytoplankton on the microbial food-web structure and functioning in our mesocosms.

\section{RESULTS AND DISCUSSION}

\section{Autotrophic and heterotrophic biomass and activity}

The 3 mesocosms differed appreciably with respect to the build up of autotrophic standing stocks (Fig. 1a) and primary production (Grossart et al. 2007). In the No Addition tank, net growth of phytoplankton was negligible, whereas a small Phaeocystis globosa bloom (chl a concentrations $2 \mu \mathrm{g}^{-1}$ ) developed on Days 12 to 14, followed by a secondary rise at the end of the

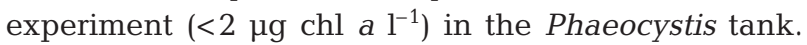
Overall, the No Addition tank represented a net heterotrophic system, whereas the autotrophic and heterotrophic activities were generally balanced in the Phaeocystis tank (Grossart et al. 2007). In the Diatom tank, a net autotrophic system developed, with chl a concentrations increasing exponentially to $55 \mathrm{\mu g} \mathrm{l}^{-1}$ at the end of the experiment (Day 20).

HNAN had mostly been removed by the pre-filtration step, but a small inoculum remained, growing to significant concentrations by Days 8 to 10 in all 3 mesocosms (Fig. 1b). The presence of phytoplankton had, however, an effect on flagellate abundance, with higher peak concentrations $\left(16 \times 10^{3}\right.$ cells ml $\left.^{-1}\right)$ in both algal tanks compared to the No Addition tank $\left(<4 \times 10^{3}\right.$ cells $\mathrm{ml}^{-1}$ ). HNAN introduced grazing pressure on bacteria during the second half of the experiment in all 3 
Table 1. List of parameters measured during the experiment, the method used, and the paper in which the data are discussed in detail. Parameters are categorized as for the clustering analysis

\begin{tabular}{|c|c|c|}
\hline Category/Parameter & Method & Source \\
\hline \multicolumn{3}{|l|}{ \% monomer composition } \\
\hline $\begin{array}{l}\text { Dissolved free neutral carbohydrate } \\
\text { (DFCHO) composition }\end{array}$ & HPLC (Mopper et al. 1992) & Grossart et al. (2007) \\
\hline $\begin{array}{l}\text { Dissolved combined neutral carbohydrate } \\
\text { (DCCHO) composition }\end{array}$ & $\begin{array}{l}\text { HPLC after acid hydrolysis } \\
\text { (Mopper et al. 1992) }\end{array}$ & Grossart et al. (2007) \\
\hline $\begin{array}{l}\text { Dissolved free amino acid (DFAA) } \\
\text { composition }\end{array}$ & $\begin{array}{l}\text { HPLC after ortho-phthaldialdehyde } \\
\text { derivatization (Lindroth \& Mopper 1979) }\end{array}$ & Grossart et al. (2007) \\
\hline $\begin{array}{l}\text { Dissolved combined amino acid } \\
\text { (DCAA) composition }\end{array}$ & $\begin{array}{l}\text { HPLC after ortho-phthaldialdehyde } \\
\text { derivatization and acid hydrolysis }\end{array}$ & Grossart et al. (2007) \\
\hline $\begin{array}{l}\text { Particulate combined amino acid } \\
\text { (PCAA) composition }\end{array}$ & $\begin{array}{l}\text { HPLC after ortho-phthaldialdehyde } \\
\text { derivatization and acid hydrolysis }\end{array}$ & Grossart et al. (2007) \\
\hline $\begin{array}{l}\text { Particulate combined neutral carbohydrate } \\
\text { (PCCHO) composition }\end{array}$ & HPLC after acid hydrolysis & Grossart et al. (2007) \\
\hline \multicolumn{3}{|l|}{ Phylotypes } \\
\hline Bacterial community composition & SSU rRNA gene (Murray et al. 1996) & Murray et al. (2007) \\
\hline \multicolumn{3}{|l|}{ Food web } \\
\hline Chlorophyll a & Fluorometer & Present paper \\
\hline Virus-like particles (VLP) & SYPER Gold counts (Chen et al. 2001) & U. Passow et al. (unpubl. data) \\
\hline Bacterial abundance & DAPI counts (Porter \& Feig 1980) & Murray et al. (2007, this issue) \\
\hline $\begin{array}{l}\text { Heterotrophic nanoflagellates (HNAN) } \\
\text { in } 3 \text { size classes }\end{array}$ & $\begin{array}{l}\text { DAPI/autofluorescence counts } \\
\text { (Kemp et al. 1993) }\end{array}$ & $\begin{array}{l}\text { Present paper, U. Passow et al. } \\
\text { (unpubl. data) }\end{array}$ \\
\hline $\begin{array}{l}\text { Autotrophic nanoflagellates (PNAN) } \\
\text { in } 3 \text { size classes }\end{array}$ & $\begin{array}{l}\text { DAPI/autofluorescence counts } \\
\text { (Kemp et al. 1993) }\end{array}$ & U. Passow et al. (unpubl. data) \\
\hline Transparent exopolymer particles (TEP) & $\begin{array}{l}\text { Colorimetric and microscopical } \\
\text { determination (Passow \& Alldredge 1995) }\end{array}$ & U. Passow et al. (unpubl. data) \\
\hline Coomassie-stained particles (CSP) & $\begin{array}{l}\text { Microscopical determination } \\
\text { (Long \& Azam 1996) }\end{array}$ & U. Passow et al. (unpubl. data) \\
\hline \multirow{3}{*}{$\begin{array}{l}\text { Hydrolysis rates of } 6 \text { complex } \\
\text { polysaccharides Community respiration } \\
\text { and net and gross production Leucine } \\
\text { hydrolysis rate }\end{array}$} & Fluorescently labeled (Arnosti 1995, 1996) & Murray et al. (2007) \\
\hline & $\begin{array}{l}\text { Change of } \mathrm{O}_{2} \text { in bottle incubations } \\
\text { (Engel et al. 2002) }\end{array}$ & Grossart et al. (2007) \\
\hline & Leucine-MCA (Hoppe et al. 1988) & Murray et al. (2007) \\
\hline \multicolumn{3}{|l|}{ Biochemical } \\
\hline $\begin{array}{l}\mathrm{PO}_{4}{ }^{3-}, \mathrm{Si}(\mathrm{OH})_{4} \text {, dissolved organic } \\
\text { phosphorus (DOP) }\end{array}$ & Manually (Strickland \& Parsons 1968) & Present paper \\
\hline $\mathrm{NO}_{3}, \mathrm{PO}_{4}^{3-}$ & Autoanalyzer & Present paper \\
\hline Particulate organic phosphorus (POP) & Manually (Koroleff 1983) & Present paper \\
\hline Particulate organic nitrogen (PON) & CHN analyzer & Present paper \\
\hline Particulate organic carbon (POC) & CHN analyzer & Grossart et al. (2007) \\
\hline Dissolved organic carbon (DOC) & High-temperature combustion & Grossart et al. (2007) \\
\hline Dissolved monosaccharides (MCHO) & TPTZ-method (Myklestad et al. 1997) & Grossart et al. (2007) \\
\hline Total dissolved carbohydrates (TCHO) & $\begin{array}{l}\text { TPTZ-method after acid hydrolysis } \\
\text { (Myklestad et al. 1997) }\end{array}$ & Grossart et al. (2007) \\
\hline $\begin{array}{l}\text { Sum of dissolved free neutral } \\
\text { carbohydrates ( } \Sigma \mathrm{DFCHO})\end{array}$ & HPLC (Mopper et al. 1992) & Grossart et al. (2007) \\
\hline $\begin{array}{l}\text { Sum of dissolved combined neutral } \\
\text { carbohydrates ( } \mathrm{DDCCHO})\end{array}$ & HPLC after acid hydrolysis & Grossart et al. (2007) \\
\hline $\begin{array}{l}\text { Sum of dissolved free amino acids } \\
\text { (IDFAA) }\end{array}$ & $\begin{array}{l}\text { HPLC after ortho-phthaldialdehyde } \\
\text { derivatization (Lindroth \& Mopper 1979) }\end{array}$ & Grossart et al. (2007) \\
\hline $\begin{array}{l}\text { Sum of dissolved combined amino acids } \\
\text { (इDCAA) }\end{array}$ & $\begin{array}{l}\text { HPLC after ortho-phthaldialdehyde } \\
\text { derivatization and acid hydrolysis }\end{array}$ & Grossart et al. (2007) \\
\hline 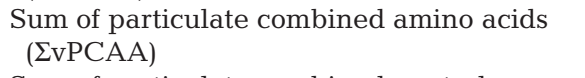 & $\begin{array}{l}\text { HPLC after ortho-phthaldialdehyde } \\
\text { derivatization and acid hydrolysis }\end{array}$ & Grossart et al. (2007) \\
\hline $\begin{array}{l}\text { Sum of particulate combined neutral } \\
\text { carbohydrates ( } \mathrm{PCCHO})\end{array}$ & HPLC after acid hydrolysis & Grossart et al. (2007) \\
\hline
\end{tabular}



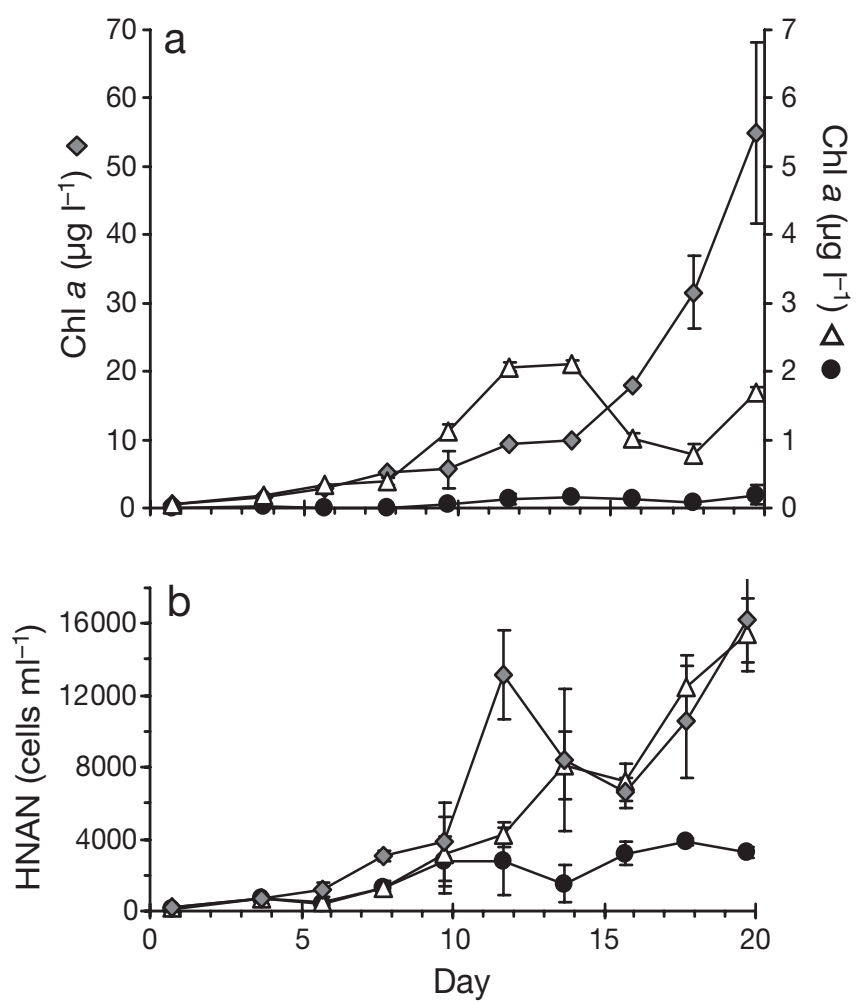

Fig. 1. Concentration of (a) chlorophyll a (chl a) and (b) heterotrophic nanoflagellates (HNAN) in the No Addition (•), Phaeocystis $(\Delta)$, and Diatom $(\diamond)$ tanks. Note the different axis scales for chl $a$. Error bars denote $\pm \mathrm{SD}$. If no error bars are visible, the $\mathrm{SD}$ is smaller than the symbol

mesocosms (U. Passow et al. unpubl. data). Grazing was estimated using the method of Gasol (1994), which suggested that HNAN concentrations during the second half of the experiment were regulated by their food (U. Passow et al. unpubl. data). Phytoplankton composition or quantity appeared to have little effect on average bacterial concentration, but height and timing of peak concentrations (Murray et al. 2007), as well as the food-web interactions differed between mesocosms (U. Passow et al. unpubl. data).

\section{Cycles of silica, nitrogen, and phosphorus}

\section{Silica cycle}

In the No Addition and Phaeocystis tanks, concentrations of silicic acid did not decrease from their initial values (Fig. 2a). In the Diatom tank, to which silicic acid had been added, concentrations barely changed until Day 10 and then decreased rapidly to about $10 \mu \mathrm{M}$ at the end of the study (Fig. 2a). Simultaneously, concentrations of BSi increased over time in the Diatom tank, mirroring the drop in silicic acid concentrations (Fig. 2b) and clearly re-
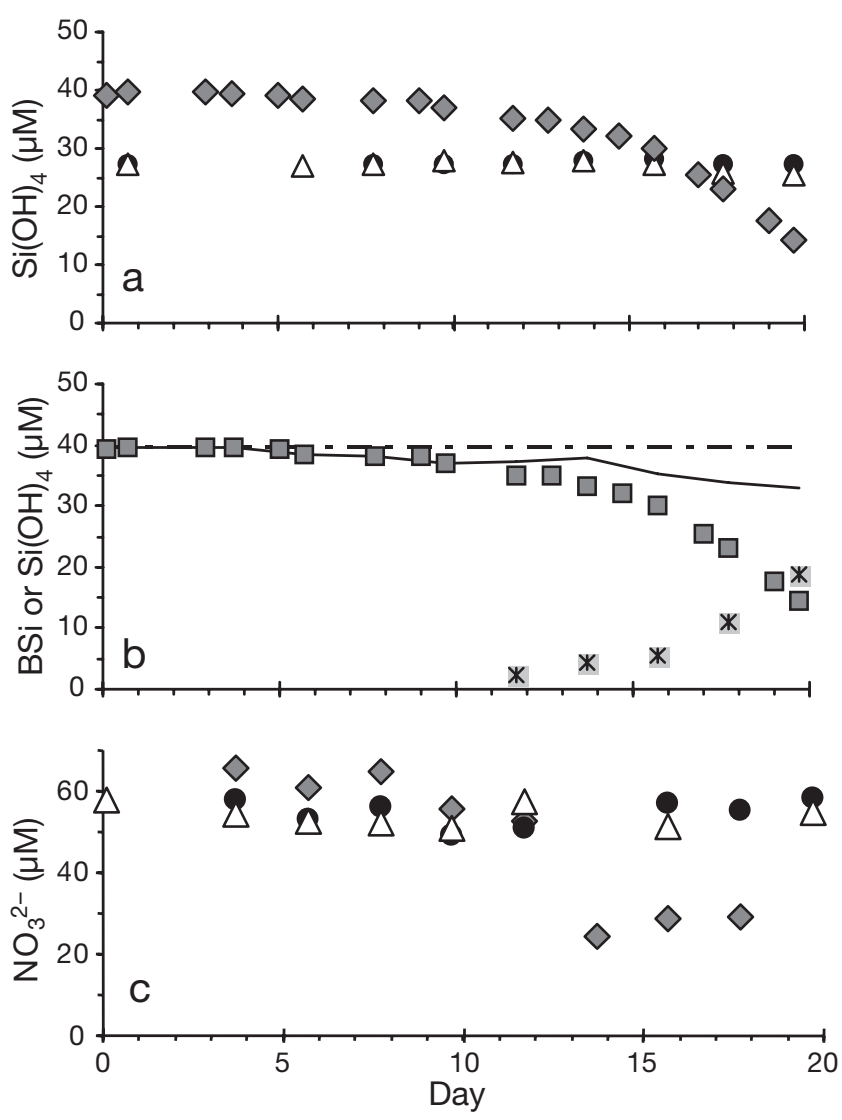

Fig. 2. Evolution of (a) silicic acid and (c) nitrate concentrations in the No Addition tank $(\bullet)$, the Phaeocystis tank $(\Delta)$, and the Diatom tank $(\diamond)$ to which silicic acid was initially added. (b) Dynamics of silica in the Diatom tank: silicic acid concentration $(\square)$, biogenic silica (BSi) concentration $(*)$, the total amount of silica (BSi + silicic acid) in the mesocosm (solid line), and the amount of silica initially present (hatched line). The difference between both lines represents the amount of silica lost, presumably due to sedimentation

flecting the growth of a diatom bloom. By about Day 14 of the experiment, the sum of suspended BSi and dissolved silicic acid was no longer equal to the concentration of silicic acid at the beginning of the experiment (Fig. 2b). This apparent loss of silicon from the tank coincided with the visible settling of diatoms to the bottom of the tank in aggregates too large to remain in suspension under the influence of the airlift system. Loss of particulates, presumably due to settling, was also observed in POC (Grossart et al. 2007).

\section{Nitrogen cycle}

Nitrate concentrations in the source water were very high $(57.6 \mu \mathrm{M})$, and some nitrate was added inadvertently to the tanks with algae during the inoculation with phytoplankton. In the No Addition and Phaeocys- 
tis tanks, no significant drop in nitrate concentrations was observed, with values fluctuating around $55 \pm 3$ and $54 \pm 3 \mu \mathrm{M}$, respectively, during the whole experiment (Fig. 2c). In the Diatom tank, nitrate concentrations decreased during the first $14 \mathrm{~d}$ of the development of the diatom bloom, but remained at $\geq 24 \mu \mathrm{M}$ thereafter. Nitrite concentrations remained stable around $0.6 \mu \mathrm{M}$ in the No Addition tank, but fluctuated more, between 0.3 and $0.7 \mu \mathrm{M}$ in both algal mesocosms. Ammonia concentrations were not monitored, but were $2.5 \mu \mathrm{M}$ in the source water. Overall growth limitation due to inorganic nitrogen sources was unlikely for all mesocosms.

PON fluctuated around low (17 $\left.\mu \mathrm{g} \mathrm{l}^{-1}\right)$ values in the No Addition tank (Fig. 3a), reflecting the presence of a small heterotrophic grazer community. In the Phaeocystis tank, PON accumulated to levels 3 times that of the No Addition tank, with concentrations peaking on Day 16 and remaining high thereafter (Fig. 3b). Peak PON lagged $2 \mathrm{~d}$ behind peak chl a concentrations of the small Phaeocystis bloom observed from Days 12 to 14. In the Diatom tank, concentrations of PON increased exponentially and, by the end of the experiment, were 25 times greater than in the No Addition tank (Fig. 3c), reflecting the exponential build up of a large diatom bloom. As nitrogen concentrations were so high that it was assumed that nitrogen was not limiting production, we focused our energies on the phosphorus cycle, and DON was not determined. The
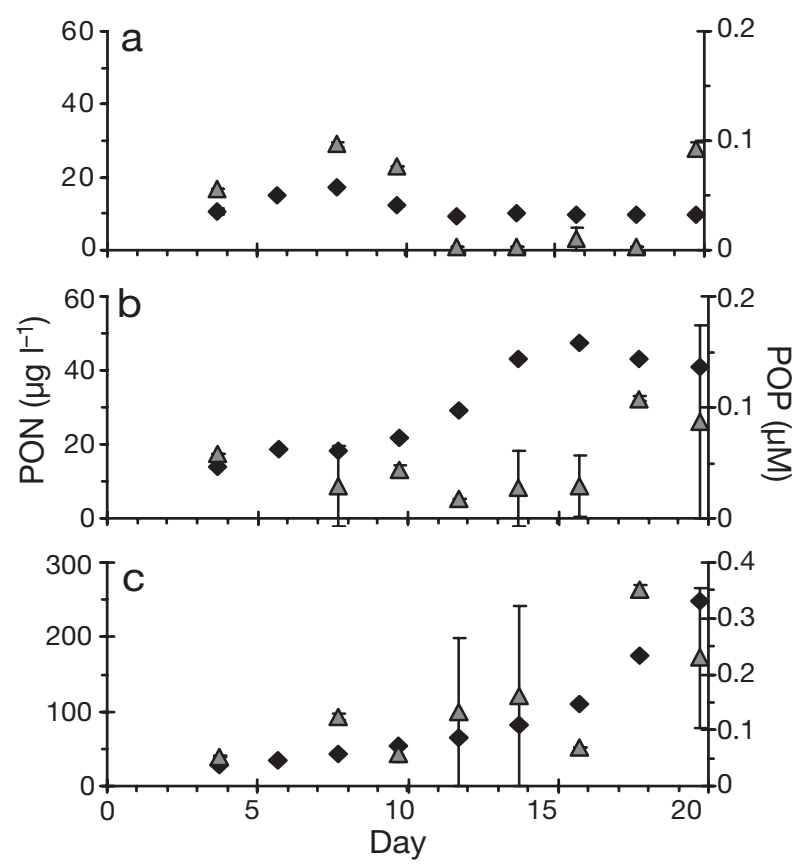

Fig. 3. Concentrations of particulate organic nitrogen (PON, -) and particulate organic phosphorus (POP, $\Delta$ ) in (a) the No Addition tank, (b) the Phaeocystis tank, and (c) the Diatom tank. Error bars are \pm SD of replicate filters. Note the difference in scales between mesocosms median DON concentration measured on 9 dates in February and April 2002 near the routine sampling station was $11.8 \mu \mathrm{M}$ (range 3.1 to $75.7 \mu \mathrm{M}, \mathrm{n}=9$, written communication from M. Schütt, Institute of Biogeochemistry and Marine Chemistry, Hamburg, Germany; confirmed by data from the MUDAB database of the Bundesamt für Seeschifffahrt und Hydrographie), implying that bioavailable DON can be, but is not necessarily, present in large amounts. At this time of the year nitrogen fixation may safely be neglected. The active participation of ammonia and DON in the cycling of nitrogen during our study is suggested by the fact that nitrate plus nitrite plus PON concentrations fluctuated by about $6 \%$ over time in the No Addition and Phaeocystis tanks. In the No Addition tank, no trend was observed in any of the measured nitrogen pools, implying that net DON concentrations did not change significantly during the experiment. An estimate based on budget calculations suggests that the build up of about

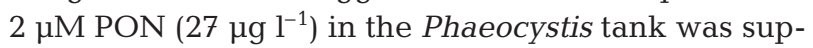
ported to $33 \%$ by nitrate, with the remaining fraction coming from DON or ammonia. An overall large decrease in the sum of nitrate, nitrite, and PON by 22 $\mu \mathrm{M}\left(308 \mu \mathrm{g} \mathrm{l}^{-1}\right)$ in the Diatom tank (the increase of 10 $\mu \mathrm{M}$ PON was offset by a decrease of $32 \mu \mathrm{M}$ nitrate) must have been the result of sedimentation and a net increase in DON in the Diatom tank. The PON loss due to sedimentation may be roughly estimated from the silica or the phosphorus budget and suggests that less than half of the lost nitrogen can be explained by sedimentation, while the remaining $>10 \mu \mathrm{M}$ augmented the ammonia or DON pool. Increases in the DON concentration are common during diatom blooms, especially if those are growing under high nitrogen conditions (e.g. Søndergaard et al. 2000). High concentrations of bioavailable nitrogen in all 3 mesocosms are also confirmed by the fact that PON closely tracked POC (Grossart et al. 2007), with a molar C:N ratio never above 6.5 (data not shown).

\section{Phosphorus cycle}

Concentrations of $\mathrm{PO}_{4}{ }^{3-}$ did not decrease significantly from initial values in the No Addition tank, whereas DOP decreased linearly over the whole study period from just above $1 \mu \mathrm{M}$ initially to undetectable concentrations on Day 20 (Fig. 4a). The heterotrophic community of the No Addition tank evidently preferred DOP over $\mathrm{PO}_{4}{ }^{3-}$, and no $\mathrm{PO}_{4}{ }^{3-}$ was used even when DOP concentrations were low $(0.2 \mu \mathrm{M})$. POP remained near the detection limit in the No Addition tank (Fig. 3a), and the particulate N:P ratio (molar) was low at $\leq 13$ until Day 10, but jumped up to an average of 183 during the next days, suggesting growth under 


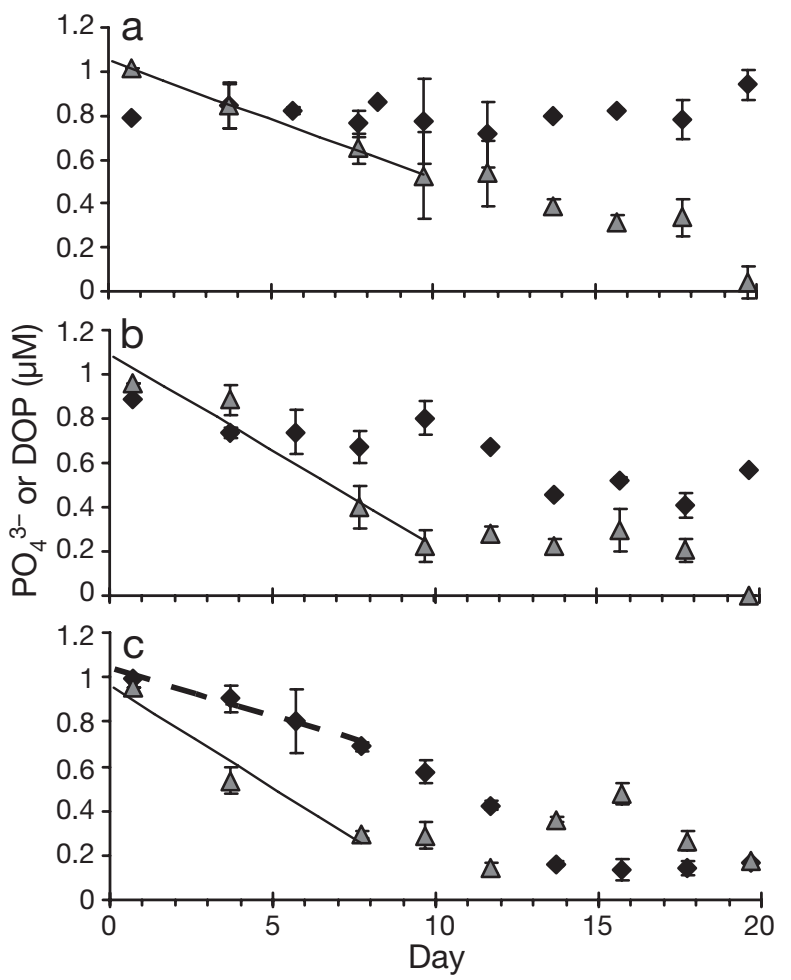

Fig. 4. $\mathrm{PO}_{4}{ }^{3-}(\diamond)$ and dissolved organic phosphorus (DOP, $\Delta$ ) concentrations in (a) the No Addition tank, (b) the Phaeocystis tank and (c) the Diatom tank. Regressions of the initial decrease in DOP (solid line) and $\mathrm{PO}_{4}{ }^{3-}$ (dashed line) are also depicted. Regressions of DOP were DOP $=-0.053 \times t+1.05, \mathrm{r}^{2}=$ $0.99 ; \mathrm{DOP}=-0.087 \times t+1.09, \mathrm{r}^{2}=0.95 ;$ and DOP $=-0.092 \times t+$ $0.96, \mathrm{r}^{2}=0.95$ in the No Addition, Phaeocystis, and Diatom tanks, respectively. During the first $10 \mathrm{~d}, \mathrm{PO}_{4}{ }^{3-}$ did not decrease significantly in the No Addition or Phaeocystis tanks and decreased with $\mathrm{PO}_{4}{ }^{3-}=-0.043 \times t+1.04, \mathrm{r}^{2}=0.97$ in the Diatom tank. Error bars for $\mathrm{PO}_{4}{ }^{3-}$ are \pm SD between manual and autoanalyzer measurements. Error bars for DOP were calculated using error propagation from $\pm \mathrm{SD}$ of total dissolved phosphorus and $\mathrm{PO}_{4}{ }^{3-}$

low phosphorus conditions after Day 10, although $\mathrm{PO}_{4}{ }^{3-}$ was available.

In the Phaeocystis tank, $\mathrm{PO}_{4}{ }^{3-}$ concentrations dropped from 0.9 to $0.7 \mu \mathrm{M}$ between Days 1 and 4 and then remained constant until Day 12 (no significant decrease between Days 1 and 12), but were drawn down to $0.5 \mu \mathrm{M}$ within $2 \mathrm{~d}$ and fluctuated around that value for the remainder of the study (Fig. 4b). The initial decrease in DOP was almost twice as fast as that in the No Addition tank, with values reaching $0.2 \mu \mathrm{M}$ already by Day 10 and remaining low for the remainder of the study (Fig. $4 \mathrm{~b})$. The higher initial rate of DOP utilization in the Phaeocystis tank compared to the No Addition tank and the initial lack of a $\mathrm{PO}_{4}{ }^{3-}$ draw down during the growth phase of the P. globosa bloom (peak: Days 12 to 14) suggest that $P$. globosa preferred DOP over $\mathrm{PO}_{4}{ }^{3-}$. P. globosa is known to grow on organic phosphorus when $\mathrm{PO}_{4}{ }^{3-}$ concentrations are $\leq 0.4 \mu \mathrm{M}$ (Veldhuis \& Admiraal 1987, van Boekel 1991). Phosphorus-limited growth by P. globosa was suggested by POP values (Fig. 3b). A significant increase in POP $(0.1 \mu \mathrm{M})$ was not observed until Day 18 in the Phaeocystis tank, 4 to $6 \mathrm{~d}$ after the P. globosa bloom peak. The particulate molar N:P ratio, which was 17 on Day 4, increased appreciably to above the Redfield ratio thereafter, with values of 115 when the $P$. globosa bloom peaked. Low phosphorus availability during growth of $P$. globosa may have been responsible for the scarcity of colonies in our experiment (U. Passow et al. unpubl. data). The effect of phosphorus availability on the formation of colonies of Phaeocystis spp. is controversial in the literature (Veldhuis \& Admiraal 1987, van Boekel 1991, Riegman et al. 1992). In our experiment, the lack of substantial colony formation allowed grazing of P. globosa flagellates by large HNAN to become a significant factor for bloom termination (U. Passow et al. unpubl. data). The growth of a population of small autotrophic flagellates after the P. globosa bloom was supported by $\mathrm{PO}_{4}{ }^{3-}$. The particulate N:P ratio decreased to 30 between Days 18 and 20, also providing evidence that phosphorus was available, even if not bioavailable for P. globosa. Clearly future studies of Phaeocystis spp. need to include detailed measurements on the cycling of phosphorus to clarify some of these issues.

In the Diatom tank, $\mathrm{PO}_{4}{ }^{3-}$ concentrations fell linearly between Days 1 and 8 (Fig. 4c) and more steeply during the next days to $<0.2 \mu \mathrm{M}$ on Day 14 , reflecting the growth of the diatoms. DOP dropped more steeply than $\mathrm{PO}_{4}{ }^{3-}$ during the first $8 \mathrm{~d}$, then fluctuated around an average low value of $0.3 \mu \mathrm{M}$ for the remainder of the experiment. A higher rate of initial DOP utilization in the Diatom tank compared to the No Addition tank is consistent with more vigorous bacterial growth during this initial phase (U. Passow et al. unpubl. data), which was also associated with a higher rate of DOC utilization (Grossart et al. 2007). Concentrations of POP increased exponentially in the Diatom tank, and were 25 times greater than in the No Addition tank by the end of the experiment (Fig. 3c). The particulate molar $\mathrm{N}: \mathrm{P}$ ratios after Day 4 were always above the Redfield ratio, fluctuating between 25 and 100, with an average of 55, implying growth conditions under low phosphorus with rapid phosphorus turn-over during growth of the diatom bloom.

\section{Synthesis: comparison between the 3 mesocosms}

\section{Differences in the start up conditions}

The 3 mesocosms were intended to initially differ only with regard to their phytoplankton population and their initial silicic acid concentration, as the origi- 
nal water as well as environmental conditions were the same in each of the mesocosms. Silicic acid concentrations were always $>10 \mu \mathrm{M}$ and are assumed not to have affected heterotrophic dynamics. However, Phaeocystis globosa could not be acquired axenically, and bacteria were added into this mesocosm along with the phytoplankton inoculum. DGGE profiles of bacteria initially present in the Phaeocystis tank were quite different (only $\sim 20 \%$ similar) from those in the other 2 tanks; however, by Day 4 , they were much more similar ( 70\%) (Murray et al. 2007), suggesting that most of the introduced bacteria vanished rapidly. In the Diatom tank, some of the introduced diatoms lysed due to the lower salinity of the mesocosm water, introducing additional DOM of a different composition than that already present (Grossart et al. 2007). This material supported a larger growth spurt of the bacterial population during the first $4 \mathrm{~d}$ compared with the development in the other 2 mesocosms (Murray et al. 2007). However, after
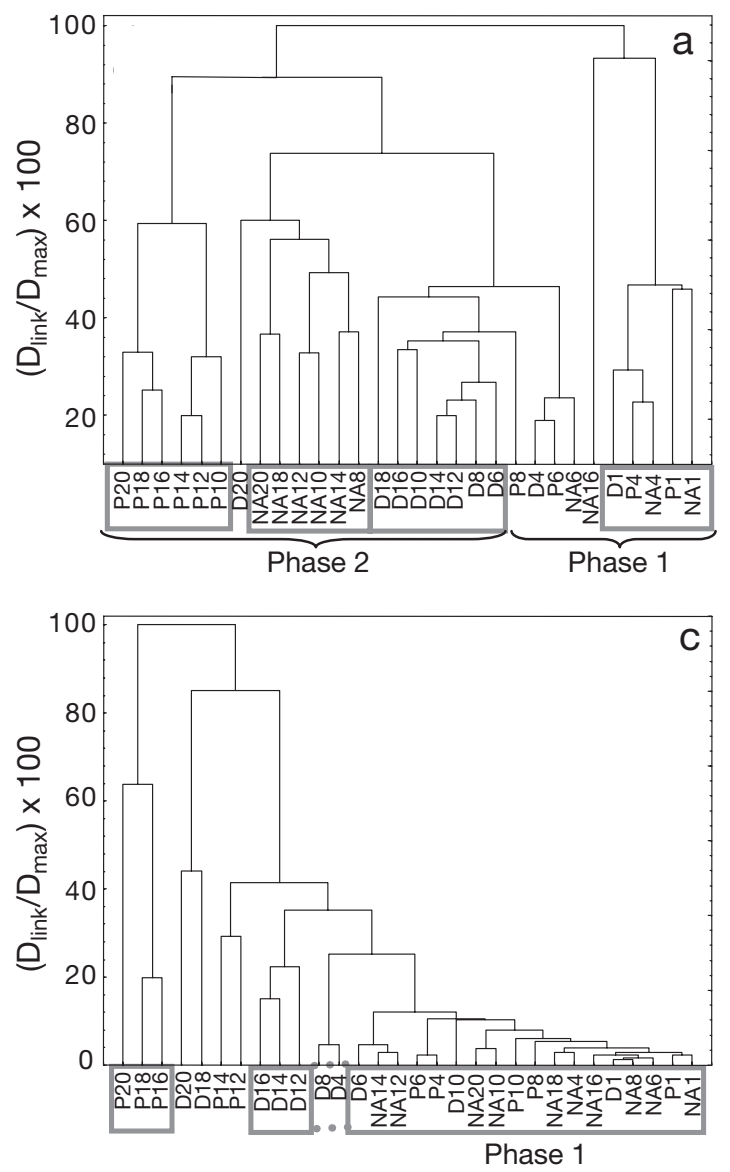

Day 4, the DOM composition and the bacterial concentration of the Diatom tank returned to conditions similar to those in the other 2 mesocosms (Grossart et al. 2007, Murray et al. 2007), suggesting that the additional DOM was removed within this time span. Bacterial activity can utilize freshly released DOM within a few days (Grossart et al. 2006). Differences between the mesocosms after Days 4 to 6 are consequently interpreted to be the direct or indirect result of the growth and activities of the differing phytoplankton populations and not the transient side effects of the inoculations themselves.

Overall comparison of the mesocosms based on all parameters measured

Comparison of averages neglects temporal trends. The 1-dimensional clustering approach used here allowed a separation of temporal trends within meso-
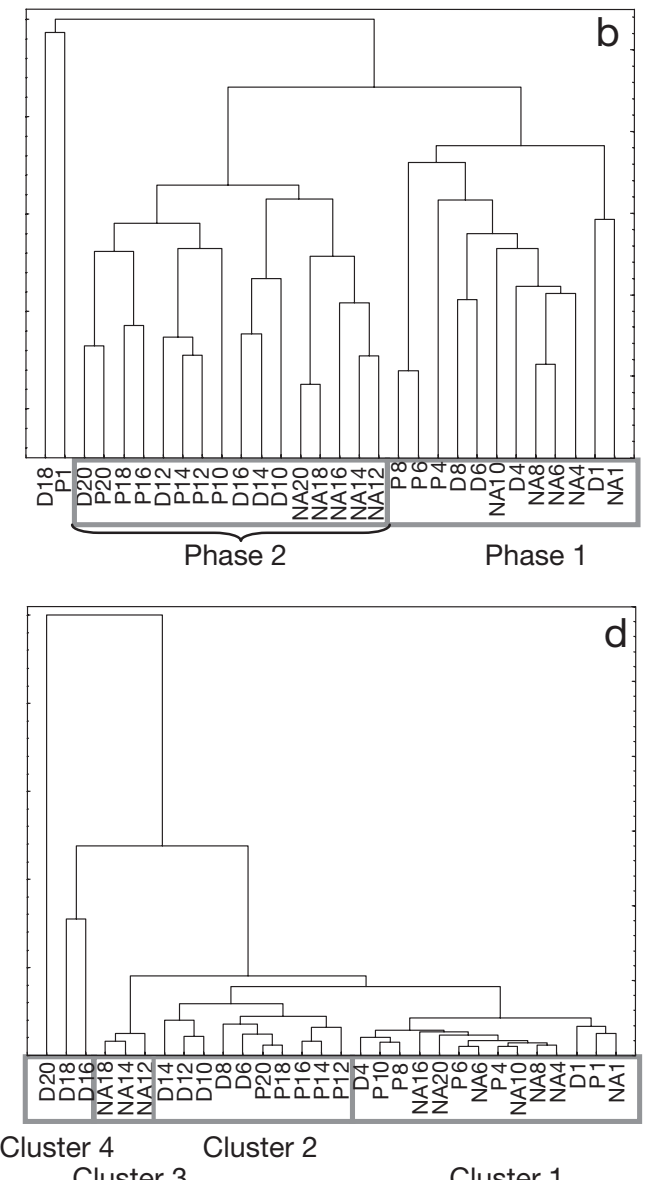

Cluster 3

Cluster 1

Fig. 5. Results of the 1-dimensional clustering analysis of samples with data grouped into 4 categories (see Table 1): (a) \% monomer composition, (b) gene phylotypes, (c) food-web data and (d) biochemical data. NA, P, and D: No Addition tank, Phaeocystis tank, and Diatom tank, respectively; numbers signify the sampling day. The distance between 2 samples as depicted on the $y$-axis ( $D_{\text {link }} / D_{\max }$ as a percent) represents the relative degree of similarity between samples. Grey outlines (solid or dotted) reflect interpretations meant to guide and structure the discussion on the clustering of data 
cosms and treatment-based differences between mesocosms (Fig. 5). This analysis allowed us to test the main hypothesis that microbial communities dominated by different phytoplankton communities would differ appreciably (1) in the composition of DOM sustained in the surrounding water, (2) in the composition of the bacterial community, (3) in the food-web structure and functioning, and (4) in the biochemical cycling. The results of the 4 clustering analyses reflect these 4 parts of the hypothesis.

The 4 dendrograms that depict the degree of similarity between samples based on the 4 categories show different patterns. The dendrogram based on the percent monomer composition (Fig. 5a) shows large relative Euclidian distances (none under 20\%), implying relatively large differences between samples. All initial mesocosm samples cluster together, mirroring the fact that initially the composition of DOM was similar in all mesocosms and affected by pre-filtration (Grossart et al. 2007). The lysing of diatoms is reflected in the percent monomer composition of D4 (Diatom tank Day 4), which falls outside the initial cluster. After Days 4 to 6 , each mesocosm clusters in its own group, indicating that the measurable fraction of the organic matter differed appreciably between mesocosms after Day 6. This suggests that phytoplankton composition did affect, either directly or indirectly, the composition of DOM appreciably. Although monomer composition of DOM changed considerably over time, temporal changes were smaller than differences between mesocosms. The very large shift $(60 \%)$ in organic matter composition of the diatom bloom on Day 20 may reflect the transition into senescence of the bloom.

The dendrogram based on DGGE phylotypes shows that both temporal and treatment-based differences in bacterial community structure were large, $>25 \%$ and up to $90 \%$ between any 2 samples (Fig. 5b). Nevertheless, the data grouped into 2 large clusters, 1 representing the first phase (up to Day 8 or 10) and 1 representing the second phase (after Day 8 or 10), and 2 'outliers', P1 (Phaeocystis tank Day 1) and D18 (Diatom tank Day 18). The outlier position of $P 1$ was caused by the addition of non-axenic inoculum, whereas that of D18 cannot be explained easily with the data available. The temporal division between the 2 large clusters suggests that the phytoplankton community composition had a relatively small effect on bacterial community composition compared to the temporal shift occurring in parallel in all 3 mesocosms. The most prominent difference between the 2 phases was the appearance of HNAN exerting grazing pressure on bacteria. We, thus, hypothesize that grazing was responsible for this temporal shift in bacterial composition. DOP concentration in all 3 mesocosms remained fairly constant during this second phase. Possibly grazing introduced some steady state with respect to DOP recycling. Although differences in DGGE phylotypes between mesocosms were small compared to these temporal changes, bacterial community structure also reflected some differences between the mesocosms, as indicated by the clustering of samples from the No Addition tanks within the cluster of Phase 2. The presence of phytoplankton per se appeared to have had a larger effect on bacterial community composition than the type of phytoplankton, as bacterial community composition in the 2 tanks with algae were not separated, also confirming that flagellate abundance (e.g. grazing) rather than phytoplankton might have been responsible for the observed differences in bacterial composition. These results gained from the clustering approach used here are in accordance with the more detailed analysis of the bacterial community composition in the companion paper by Murray et al. (2007).

A different picture emerges when looking at the dendrogram based on food-web structure, where all samples from the No Addition tank, the first $10 \mathrm{~d}$ of the Phaeocystis tank, and many Diatom tank samples from the early phase were grouped together in a cluster (Fig. 5c), with a relatively high degree of similarity $(<20 \%$ difference). This suggests that, during the first phase of the experiment, development in standing stocks and activities were similar in all mesocosms, and dominated by the start up conditions, e.g. inoculation and pre-filtration. The initial lysis event in the Diatom tank was probably responsible for the slightly different grouping of samples from Days 4 and 8. The cluster analysis furthermore implies that food-web structure in the No Addition tank changed little over time. Food webs in both algal mesocosms developed differently (different clusters) during the second phase, after Day 10 , and went through large temporal changes, as represented by the large Euclidian distance between consecutive samples. These temporal changes reflect large differences in organism and particle concentrations, as well as in primary production, community respiration, and hydrolysis rates of leucine, whereas the extracellular hydrolysis rates of 6 complex polysaccharides were remarkably similar in all 3 mesocosms (Murray et al. 2007). On average, the enzymatic hydrolysis of 6 different complex polysaccharides appeared unaffected by autotrophic production, whereas average leucine hydrolysis differed significantly between mesocosms, with higher values in mesocosms with higher primary production (Murray et al. 2007).

The results of the clustering analysis of the biochemical parameters (Fig. 5d) suggest that all samples were very similar, with a relative Euclidian distance of $<20 \%$, except for the samples from the last days of the experiment (Days 16 to 20) from the Diatom tank. Although comparably similar, samples grouped into 4 
clusters, reflecting different levels of biomass. The first cluster contained all samples with very low biomass, e.g. Diatom tank samples on or before Day 4, Phaeocystis tank samples on or before Day 10, and both initial and late No Addition tank samples. Biomass in the No Addition tank fluctuated during the experiment. The second cluster contained samples of slightly elevated biomass, including samples from the late Phaeocystis and intermediate samples from the Diatom tank. The third cluster includes some intermediate to late samples from the No Addition tank, emphasizing the difference between the No Addition and the 2 tanks with algae. Samples from the last days of the experiment from the Diatom tank underwent large temporal changes as the bloom grew, reflected in the high degree of dissimilarity between the individual samples of this fourth cluster. The biomass build up, which is a quantitative rather than qualitative process, dominated the clustering of the biochemical parameters more than any other single process.

The clustering analysis suggests that parts of our hypothesis were accurate in our mesocosm system, whereas other parts can be rejected. Phytoplankton composition affected DOM composition after only $6 \mathrm{~d}$, and food-web structure in the 3 mesocosms diverged after $10 \mathrm{~d}$. In terms of biochemical cycling, the Diatom tank digressed from the other 2 mesocosms after about $14 \mathrm{~d}$, reflecting differences in biomass production. The effect of phytoplankton on bacterial community composition was unexpectedly small, with the modest, distinct development in the No Addition tank after Day 12. However, temporal changes in bacterial community composition were marked.

\section{OVERALL SUMMARY AND CONCLUSIONS}

The overarching goal of this mesocosm study was to characterize the effect of phytoplankton on the associated microbial food webs. The 3 mesocosms developed divergently in terms of autotrophic build up of organic carbon: a net heterotrophic system prevailed in 1 mesocosm, an overall balanced system with a small bloom of Phaeocystis globosa existed in the second, and a large diatom bloom formed in the third mesocosm. Considering these large quantitative and qualitative differences in autotrophs between the 3 mesocosms the differences in the structure and function of the associated microbial loops were small. Initial inspection of the very large data set led to the impression that organic matter composition and the heterotrophic grazer communities of the different mesocosms appeared not to differ significantly from each other. Using statistical pattern recognition tools, it was, however, possible to tease the differences apart and iden- tify interesting connections between phytoplankton and the other components of the microbial loop.

The cycling of phosphorus differed appreciably as a function of phytoplankton, with DOP utilized preferentially by Phaeocystis globosa and $\mathrm{PO}_{4}{ }^{3-}$ utilized by diatoms.

After about $6 \mathrm{~d}$, the organic matter composition (to the degree it was measurable, 20 to $70 \%$ ) developed differently as a function of phytoplankton composition, and each mesocosm displayed its own distinct organic matter signature. However, overall DOC concentrations and dynamics were similar in all mesocosms, and were hiding the compositional differences (Grossart et al. 2007).

Turnover of freshly released material, especially amino acids appeared larger in the presence of algae compared to in the heterotrophic mesocosm (Grossart et al. 2007), leading to higher bacterial leucine uptake rates (Murray et al. 2007).

Peak concentrations of flagellates were higher in the algal mesocosms than in the No Addition tank, as food availability was higher in the algal mesocosms (U. Passow et al. unpubl. data). The quantitative difference between the autotrophic biomass in both tanks with algae was, however, not reflected in flagellate numbers. In our experiments, the presence or absence of autotrophs, which introduced organic matter into the system rather than phytoplankton composition or quantity, appeared relevant in determining flagellate numbers (U. Passow et al. unpubl. data).

After about $10 \mathrm{~d}$, food-web structure developed somewhat divergently in all 3 mesocosms, with differences visible in the feeding relationships. Higher flagellate numbers compared to the No Addition tank were, for example, supported by elevated concentrations of bacteria in the Phaeocystis tank and by higher TEP concentrations in the Diatom tank (U. Passow et al. unpubl. data). High concentrations of HNAN $>6 \mu \mathrm{m}$ were only supported in the Phaeocystis tank (U. Passow et al. unpubl. data). Rapid temporal change in all mesocosms overlaid these developments.

Bacterial community composition was minimally affected by phytoplankton composition, and temporal variation was as large as differences between mesocosms, obscuring possible differences caused by different autotrophic communities. Two phases were visible in the bacterial community composition of all mesocosms. Possibly high grazing pressure during the second phase was responsible for this shift.

Although differences were observed in the hydrolysis of individual polysaccharides, which could be related to community composition, the temporal changes in patterns were similar among mesocosms, suggesting that polysaccharide turn-over was largely independent of phytoplankton species, but a function of bacterial community composition. 
The microbial loop systems investigated in this study were simple compared to natural ones, where a more diverse population of protists is to be expected. Prefiltration had eliminated fragile and larger protists. Nevertheless, this study allows some insights into the effect of phytoplankton on the structure and function of the associated microbial loop systems, which could not have been investigated in situ. Our results suggest that large quantitative differences in the phytoplankton concentration ( $\mathrm{chl} \mathrm{a)} \mathrm{result} \mathrm{in} \mathrm{relatively} \mathrm{small} \mathrm{differences} \mathrm{in}$ the heterotrophic and non-living compartments. A more complex food web, as is common in nature, is likely to level out potential quantitative differences in the nonautotrophic biomass even more. Qualitative differences in phytoplankton composition were reflected in DOM composition, but not echoed in bacterial community composition. These results suggest that differences in bacterial community composition and specific polysaccharide hydrolysis rates between different natural systems might be small even if DOM composition is likely to vary. This could mean that the organic substances commonly generated in marine systems may be utilized equally well by a large fraction of cosmopolitan marine bacteria. Alternatively, this result could also have been caused by an inadvertent selection of bacteria adapted well to the growth conditions in our mesocosms. This is supported by indications that hydrolysis rates were related to bacterial community composition. These possibilities need to be addressed in future studies. In our experiment bacterial community composition appeared to be largely a function of the grazer population, implying that top-down rather than bottom-up control determined bacterial community composition. A more complicated food web, where the bacterial predators are themselves under more severe grazing pressure, may result in a shift towards bottom-up control of bacterial community composition.

Acknowledgements. Considerable thanks to S. Schlake, M. Schmidt and L. von Harbou for all of their hard work during sampling and counting. R. Amon, C. Heemann, A. Terbrueggen, M. Stuerck, and G. Langer also provided invaluable assistance with protocols, supplies, and equipment. This research was supported by the Alfred Wegener Institute for Polar and Marine Research, the Natural Environment Research Council (Grant NER/B/S/ 2000/00735 to C.L.D.), Desert Research Institute, and NSF (Grant OPP-0085435 to A.E.M. and Grants OCE-9906089 and -0323975 to C.A.). C.A. was a fellow of the Hanse-Wissenschaftskolleg (Delmenhorst) while participating in this project.

\section{LITERATURE CITED}

Alldredge AL, Gotschalk C, Passow U, Riebesell U (1995) Mass aggregation of diatom blooms: insights from a mesocosm study. Deep-Sea Res 42:9-28

Arnosti C (1995) Measurement of depth-related and site- related differences in polysaccharide hydrolysis rates in marine sediments. Geochim Cosmochim Acta 59: $4247-4257$

Arnosti C (1996) A new method for measuring polysaccharide hydrolysis rates in marine environments. Org Geochem 25:105-115

Azam F, Fenchel T, Field GJ, Gray JS, Meyer-Reil LA, Thingstad F (1983) The ecological role of water column microbes in the sea. Mar Ecol Prog Ser 10:257-263

Brussaard CPD, Mari X, Van Bleijswijk JDL, Veldhuis MJW (2005) A mesocosm study of Phaeocystis globosa (Prymnesiophyceae) population dynamics. II. Significance for the microbial community. Harmful Algae 4:875-893

Castberg T, Larsen A, Sandaa RA, Brussaard CPD and 5 others (2001) Microbial population dynamics and diversity during a bloom of the marine coccolithophorid Emiliania huxleyi (Haptophyta). Mar Ecol Prog Ser 221:39-46

Chen F, Lu JR, Binder BJ, Liu YC, Hodoson RE (2001) Application of digital image analysis and flow cytometry to enumerate marine viruses stained with SYBR Gold. Appl Environ Microbiol 67:539-545

Egge JK, Aksnes DL (1992) Silicate as regulating nutrient in phytoplankton competition. Mar Ecol Prog Ser 83: 281-289

Engel A, Goldthwait S, Passow U, Alldredge A (2002) Temporal decoupling of carbon and nitrogen dynamics in a mesocosm diatom bloom. Limnol Oceanogr 47:753-761

Fandino LB, Riemann L, Steward GF, Long RA, Azam F (2001) Variations in the bacterial community structure during a dinoflagellate bloom analyzed by DGGE and 16S rDNA sequencing. Aquat Microb Ecol 23:119-130

Fuhrman JA (1999) Viruses and their biogeochemical and ecological effects. Nature 399:541-548

Gasol JM (1994) A framework for the assessment of top-down versus bottom-up control of heterotophic nanoflagellate abundance. Mar Ecol Prog Ser 113:291-300

Grossart HP, Czub G, Simon M (2006) Algae-bacteria interactions and their effects on aggregation and organic matter flux in the sea. Environ Microbiol 8:1074-1084

Grossart HP, Engel A, Arnosti C, De La Rocha CL, Murray AE, Passow U (2007) Microbial dynamics in autotrophic and heterotrophic seawater mesocosms. III.Organic matter fluxes. Aquat Microb Ecol 49:143-156

Havskum H, Thingstad TF, Scharek R, Peters F and 6 others (2003) Silicate and labile DOC interfere in structuring the microbial food web via algal-bacterial competition for mineral nutrients: results of a mesocosm experiment. Limnol Oceanogr 48:129-140

Hoppe HG, Kim SJ, Gocke K (1988) Microbial decomposition in aquatic environments: combined process of extracellular enzyme activity and substrate uptake. Appl Environ Microbiol 54:784-790

Kemp PF, Sherr BF, Sherr EB, Cole JJ (1993) Handbook of methods in aquatic microbial ecology. Lewis Publishers, London

Koroleff F (1983) Determination of nutrients. In: Grasshoff K, Erhardt M, Kremling K (eds) Methods of seawater analysis. Verlag Chemie, Weinheim, p 125-187

Larsen A, Castberg T, Sandaa RA, Brussaard CPD and 6 others (2001) Population dynamics and diversity of phytoplankton, bacteria and viruses in a seawater enclosure. Mar Ecol Prog Ser 221:47-57

Lebaron P, Servais P, Trousselier M, Courties C and 6 others (1999) Changes in bacterial community structure in seawater mesocosms differing in their nutrient status. Aquat Microb Ecol 19:255-267

Lebaron P, Servais P, Trousselier M, Courties C and 7 others 
(2001) Microbial community dynamics in Mediterranean nutrient-enriched seawater mesocosms: changes in abundances, activity and composition. FEMS Microbiol Ecol 34: 255-266

Lindroth P, Mopper K (1979) High performance liquid chromatography determination of subpicomole amounts of amino acids by precolumn fluorescence derivatisation with OPA. Anal Chem 51:1667-1674

Long RA, Azam F (1996) Abundant protein-containing particles in the sea. Aquat Microb Ecol 10:213-221

Meon B, Kirchman D (2001) Dynamics and molecular composition of dissolved organic material during experimental phytoplankton blooms. Mar Chem 75:185-200

Mopper K, Schultz A, Chevolot L, German, C, Revuelta R, Dawson R (1992) Determination of sugars in unconcentrated seawater and other natural waters by liquid chromatography and pulsed amperometric detection. Environ Sci Technol 26:133-138

Murray AE, Hollibaugh JT, Orrego C (1996) Phylogenetic compositions of bacterioplankton from two California estuaries compared by denaturing gradient gel electrophoresis of 16S rDNA fragments. Appl Environ Microbiol 62:2676-2680

Murray AE, Arnosti C, De La Rocha CL, Grossart HP, Passow U (2007) Microbial dynamics in autotrophic and heterotrophic seawater mesocosms. II. Bacterial community structure and hydroliytic enzyme activities. Aquat Microb Ecol 49:123-141

Myklestad SM, Skanoy E, Hestmann S (1997) A sensitive and rapid method for analysis of dissolved mono- and polysaccharides in seawater. Mar Chem 56:279-286

Øvreås L, Bourne D, Sandaa RA, Casamayor EO and 5 others (2003) Response of bacterial and viral communities to nutrient manipulations in seawater mesocosms. Aquat Microb Ecol 31:109-121

Passow U (2002) Production of transparent exopolymer particles (TEP) by phyto- and bacterioplankton. Mar Ecol Prog Ser 236:1-12

Passow U, Alldredge AL (1995) A dye-binding assay for the spectrophotometric measurement of transparent exopolymer particles (TEP). Limnol Oceanogr 40:1326-1335

Pinhassi J, Azam F, Hemphälä J, Long RA, Martinez J, Zweifel UL, Hagström Å (1999) Coupling between bacterioplankton species composition, population dynamics, and organic matter degradation. Aquat Microb Ecol 17:13-26

Porter KG, Feig YS (1980) The use of DAPI for identifying and

Editorial responsibility: Craig Carlson, Santa Barbara, California, USA counting aquatic microflora. Limnol Oceanogr 25:943-948 Riegman R, Noordeloos AM, Cadee GC (1992) Phaeocystis blooms and eutrophication of the continental coastal zones of the North Sea. Mar Biol 112:479-484

Riemann L, Steward GF, Azam F (2000) Dynamics of bacterial community composition and activity during a mesocosm diatom bloom. Appl Environ Microbiol 66:578-587

Schäfer H, Bernard L, Courties C, Lebaron P and 7 others (2001) Microbial community dynamics in Meditarreanean nutrient-enriched seawater mesocosms: changes in the genetic diversity of bacterial populations. FEMS Microbiol Ecol 34:243-253

Šimek K, Hartman P, Nedoma J, Pernthaler J, Springmann D, Vrba J, Psenner R (1997) Community structure, picoplankton grazing and zooplankton control of heterotrophic nanoflagellates in a eutrophic reservoir during the summer phytoplankton maximum. Aquat Microb Ecol 12:49-63

Šimek K, Armengol J, Comerma M, Garcia JC, Kojecka P, Nedoma J, Hejzlar J (2001) Changes in the epilimnetic bacterial communty composition, production, and protistinduced mortality along the longitudinal axis of a highly eutrophic reservoir. Microb Ecol 42:359-371

Søndergaard M, Williams PJleB, Cauwet G, Riemann B, Robinson C, Terzic S, Woodward EMS, Worm J (2000) Net accumulation and flux of dissolved organic carbon and dissolved organic nitrogen in marine plankton communities. Limnol Oceanogr 45:1097-1111

Strickland J, Parsons T (1968) A practical handbook of seawater analysis. Bull Fish Res Board Can 167

Troussellier M, Got P, Mboup M, Corbin D, Giuliano L, Capello S, Bouvy M (2005) Daily bacterioplankton dynamics in a sub-Saharan estuary (Senegal River, West Afrika): a mesocosm study. Aquat Microb Ecol 40:13-24

van Boekel WHM (1991) Ability of Phaeocystis sp. to grow on organic phosphates: direct measurement and prediction with the use of an inhibition constant. J Plankton Res 13: 959-970

Veldhuis MJW, Admiraal W (1987) Influence of phosphate depletion on the growth and colony formation of Phaeocystis pouchetii. Mar Biol 95:47-54

Wassman P, Passow U, Vernet M (1995) A new hypothesis on the fate of extracellular carbon released by phytoplankton in arctic shelf areas. In: Floderus S, Wassmann $\mathrm{P}$, Heiskanen AS (eds) Sediment trap studies in the Nordic countries. 3. Proceedings. NurmiPrint, Nurmijärvi, p 106-116

Submitted: December 19, 2006; Accepted: August 20, 2007 Proofs received from author(s): November 3, 2007 